\title{
Effect of Heat Treatment on Properties of Titanium Biomedical Alloy
}

\author{
Jassim M. Salman Al-Murshdy \\ Bassim Jaber Ghayyib \\ College of Materials Engineering, Babylon University
}

jmsmaterials@yahoo.com

bassimjaber888@gmail.com

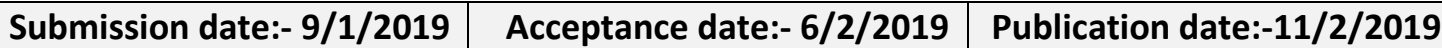

\begin{abstract}
The aim of this work to study the effects of heat treatments on the alloy (Ti6Al4V) which produced by powder metallurgy methods and consists of a mixture of the following powders (titanium $90 \%$, aluminum $6 \%$ and vanadium $4 \%$ ). The heat treatments (sintering process) take place in different time of stay. The alloy (Ti6Al4V) used as biomaterials in the medical field due to their excellent properties such as : high corrosion resistance, high wear resistance, high breaking strength, higher ductility, non-toxic and non-magnetic, suitable elasticity coefficient, where used as an alternative to replacing damaged hard tissues such as orthopaedic, osteosynthesis, full hip joint, knee joint and dental implants. The elements were weighed by a highly sensitive electronic balance, the powder was mixed for five hours, Then press with a pressure $(700 \mathrm{MPa})$ to transition to green cylindrical samples with a diameter of $13 \mathrm{~mm}$. The sintering process was carried out at $1100{ }^{\circ} \mathrm{C}$. The porosity of the samples decreases at high temperatures and time of stay to a certain extent and then increase porosity at very high temperatures due to the growth of particle and the expansion of gases. The density of the samples after the sintering process increases with increasing the temperature because increase the mass diffusion of particles and reduces porosities that increase contact points between particles. The sintering processes lead to increase the hardness, where the hardness was tested in the Vickers hardness method. The wear increased by increasing (load, time and sliding distance), and increase the hardness leads to a low volume loss (the amount of metal lost a few) as the relationship between them is inverse. To study the corrosion behavior of the samples that have been sintering processes under different time of stay and to perform this test (tafel Extrapolation test) in $0.9 \mathrm{NaCl}$ solution, where the sample is subjected to high temperature and a long period of stay and therefore This lead to increases the diffusion and increases the contact points between the particles and increase the forces of bonds between the particles and this leads to increased corrosion current and therefore the oxidation process to be a high degree and this leads to the higher rate of corrosion.
\end{abstract}

Keyword: Biomedical alloy, Ti alloy, Heat treatments, Mechanical properties.

\section{Introduction}

Titanium alloys are important materials for biomedical applications, in both medical and dental fields. The request for titanium and its alloys has grown a lot since the 1970s because excellent properties such as: high corrosion resistance, high wear resistance, good fracture toughness, higher ductility, non-toxic and non-magnetic, suitable elasticity coefficient, high Biocompatibility, high strength, light weight [1],[2]. Titanium alloy is known by its light weight, the density of this alloy is just $\left(4.5 \mathrm{~g} / \mathrm{cm}^{3}\right)$ comparing to $\left(7.9 \mathrm{~g} / \mathrm{cm}^{3}\right)$ 316-stainless steel, $\left(8.3 \mathrm{~g} / \mathrm{cm}^{3}\right)$ Co-Cr-Mo alloys. Titanium and its alloys (Ti-6Al-4V) are favour for their superior both resistance of pitting corrosion and strength of tensile [3]. The biomedical Titanium alloys also have a higher strength to the density ratio comparison to Co-Cr and stainless steel alloys. It is known that titanium is completely inert and resistant to corrosion in all fluids and tissues of the body, there for it is full bio compatibility. The elasticity coefficient of titanium (Ti) and its alloys is near to elasticity coefficient of the bone and much less than the cobalt-chromium and stainless steel alloys [4]. The titanium dealing with living tissues there for must have the following properties; tensile strength, non-toxic, high corrosion resistance, biocompatibility (accepted by living tissues) and have suitable mechanical properties such as wear resistance, hardness, fatigue limit, and Young's modulus[5]. Titanium has an excellent resistance of corrosion by itself [6]. When titanium reacts with oxygen produces an adherent layer and inert oxide that is the cause of excellent-corrosion resistance of titanium [7]. 
Titanium alloys have to be higher biocompatibility as a comparison with cobalt-based and stainlesssteel alloys and that return to superior resistance of titanium to corrosion [6]. Bio-compatibility is one of the most important properties that make the material implants in the human body used for a longtime[4]. From proprieties of Biocompatible materials do not cause allergic interaction or inflammatory, non-toxic, and should not weaken functions at any level. In an optimum state titanium has the ability for osseointegrations with bones [1].

\section{Experimental Work}

Materials for research are being prepared. Equipment used in the preparation of samples is prepared, sintering process are illustrated. In addition to done several tests such as Corrosion resistance, Hardness, Microstructure test, SEM test and Wear resistance.

\subsection{Materials}

The materials powders utilized to prepare the alloy (Ti6Al4V) which used in this research are illustrated in table (1) with average particle size and the purity.

\section{Table (1) Purity \% and average particle size of materials}

\begin{tabular}{|c|c|c|}
\hline Material (powder) & Purity $\%$ & Average particle size $(\mu \mathrm{m})$ \\
\hline Titanium & 99.98 & 125.1 \\
\hline Aluminum & 99.95 & 25.85 \\
\hline Vanadium & 99.5 & 19.56 \\
\hline
\end{tabular}

The stress applied on the metallic powders in order to obtain green compacting samples was (700MPa). Incubation time was (4min) in state applied stress. Graphite powder used with about $(40 \mu \mathrm{m})$ particle size as lubricator to the die.

1- Heating Samples until $\left(500^{\circ} \mathrm{C}\right)$.

2- Soaking for (2) hours at $500^{\circ} \mathrm{C}$.

3- Heating from $\left(500{ }^{\circ} \mathrm{C}\right)$ to $\left(1100{ }^{\circ} \mathrm{C}\right)$.

4- Soaking for (1, 2 and 3$)$ hours at $\left(1100^{\circ} \mathrm{C}\right)$.

5- Slow cooling in the furnace to the room temperature.

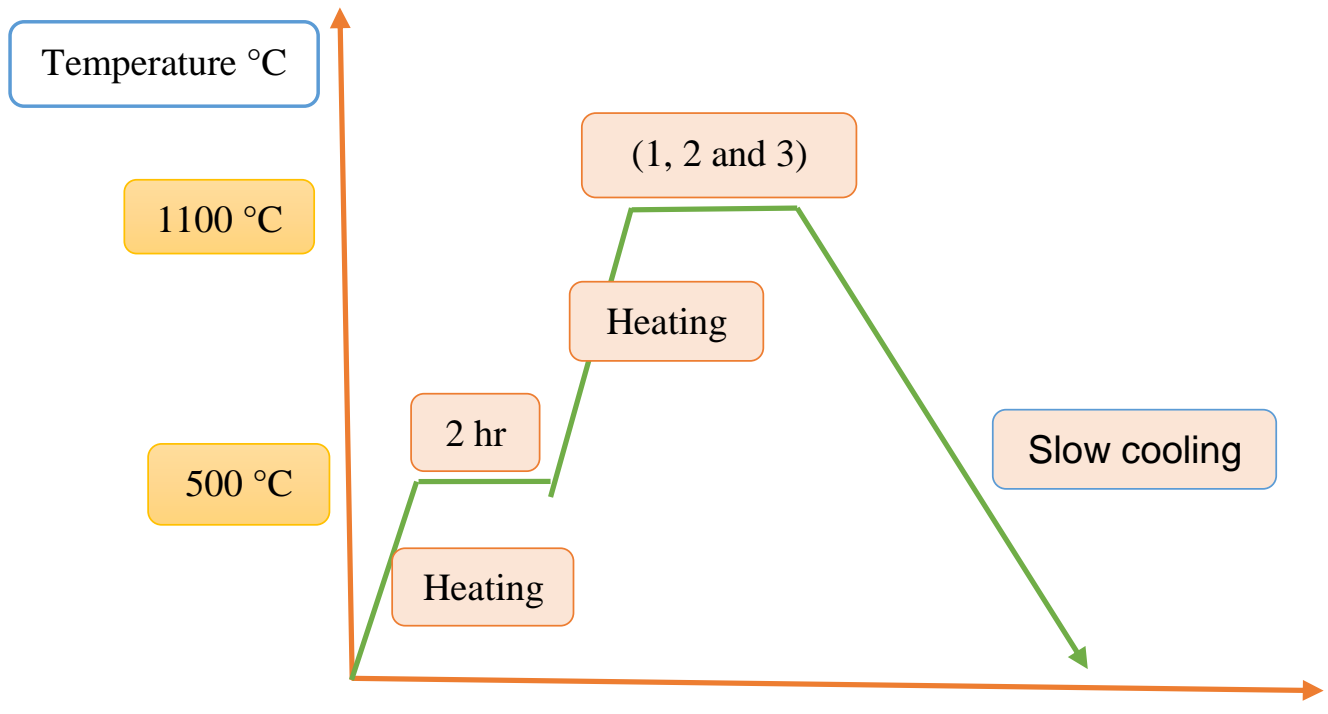

Figure (1): Heating cycle in sintering 


\subsection{Preparation of Samples for the Testing}

The samples were ground after sintering process by using different granular silicon carbide papers, and then polished with a diamond with $(15 \mu \mathrm{m})$ to obtain a bright mirror complete to final step. Etching was made at room temperature, the chemical composition of the etching solution is in Table (2) [8]. For prepared samples are immersed in etching solution for (5-10) seconds, after etching process the samples were washed with distilled water and dried.

\section{Table (2) Chemical composition of etching solution [9].}

\subsection{Vickers Hardness}

\begin{tabular}{|c|c|c|}
\hline NO. & Constituents & $\mathrm{mL}$ \\
\hline 1 & $\mathrm{HF}$ & 10 \\
\hline 2 & $\mathrm{HNO}_{3}$ & 5 \\
\hline 3 & water & 85 \\
\hline
\end{tabular}

Microhardness Vickers's instrument used to measure the hardness of the samples with (500 gm) as applying weight and the incubation time was $(10 \mathrm{sec})$ in state applied weight. Three measurements for every sample had been taken and the average values are used to analysis behavior of the alloys. by using a micro-hardness tester HVS 1000 [9].

\subsection{Dry Sliding Wear Test}

The samples must be dry before using wear test, there for The samples are dried at $\left(50{ }^{\circ} \mathrm{C}\right)$ for ( $2 \mathrm{hr}$ ) and cooled in the furnace, this process has been done by using vacuum drying furnace, then the samples must keep completely dry. The dry wear test takes place by using $(350 \mathrm{rpm})$ with radius $(6 \mathrm{~mm})$ constant and the loads were $(10 \mathrm{~N}, 15 \mathrm{~N}$ and $20 \mathrm{~N})$. The sample is weighted before test by using (0.0001) accuracy electric balance. After a period of time $(5,10,15,20$ and $25 \mathrm{~min})$ the sample test is weighted and the dry sliding wear rate had determined according to equation (1) [10].

$$
\text { Volume Loss }=[\text { weigth loss }(\mathrm{g})] /\left[\rho\left(\mathrm{g} /\left(\mathrm{cm}^{3}\right)\right)\right] \text {--------------- (1) [11] }
$$

Where:

Weight loss $(\mathrm{g})=$ quantity loss after $(5,10,15,20$ and 25$) \mathrm{min}$.

$\rho\left(\mathrm{g} / \mathrm{cm}^{3}\right)=$ theoretical density of the element formed for the specimen Calculated from following equation:

$$
\rho \mathrm{tB}=\boldsymbol{\Sigma} \mathrm{Wt} 1 * \rho 1+\mathrm{Wt} 2 * \rho 2+\mathrm{Wt} 3 * \rho 3+\ldots .+\mathrm{Wtn} * \rho \mathrm{n}
$$

\subsection{Electrochemical Test}

The corrosion behavior of titanium alloys studied in solution simulated human body fluid such as $(0.9 \% \mathrm{NaCl})$. The chemical composition of $(0.9 \mathrm{NaCl})$ solution is illustrated in tables (3) [12].

Table (3): Higher Concentrated Body Fluid (0.9\% NaCl) $(\mathrm{PH}=6.2)$

\begin{tabular}{|c|c|c|}
\hline $\mathrm{No}$ & Constituents & $(\mathrm{g} / \mathrm{L})$ \\
\hline 1 & $\mathrm{NaCl}$ & 8.035 \\
\hline 2 & $\mathrm{MgCl} .6 \mathrm{H}_{2} \mathrm{O}$ & 0.311 \\
\hline 3 & $\mathrm{~K}_{2} \mathrm{HPO}_{4} .3 \mathrm{H}_{2} \mathrm{O}$ & 0.231 \\
\hline 4 & $\mathrm{NaHCO}_{3}$ & 0.355 \\
\hline 5 & $\mathrm{CaCl}_{2}$ & 0.292 \\
\hline 6 & $\mathrm{Na}_{2} \mathrm{SO}_{4}$ & 0.072 \\
\hline
\end{tabular}




\subsubsection{Potentiodynamic polarization}

Electrochemical test was performed in electrode cell containing electrolyte similar to nature $(0.9 \mathrm{NaCl})$. The reference electrode was SCE [Saturated Calomel Electrode], and the counter electrode was Pt electrode and the working electrode (samples). The user potential (rate of scanning $0.4 \mathrm{mV} / \mathrm{s}$ ) from initial potential which have value $(350 \mathrm{mV})$ [13]. Potentiodynamic curves of polarization are drawing and both corrosion potential and (icorr) corrosion current density are evaluated by Tafel plots by utilized anodic with cathodic branches.

$$
\text { Corrosion rate }=0.13 \text {. (icorr).(EW) } / \rho \ldots \ldots \ldots \ldots \ldots \ldots \ldots . .(3)[11]
$$

Where:

mpy $=$ Corrosion rate $($ mils per year)

icorr is corrosion current density $\left(\mu \mathrm{A} / \mathrm{cm}^{2}\right)$

$\rho$ is density $\left(\mathrm{g} / \mathrm{cm}^{3}\right)$

$0.13=$ metric and time conversion factor

EW is equivalent weight $(\mathrm{g} / \mathrm{eq})=.\sum(\mathrm{f} * \mathrm{n}) / \mathrm{a}$ (4) [11]

$\mathbf{f}=$ weigth of element in alloy, $\mathbf{n}=$ most common valence, $\mathbf{a}=$ atomic weight

\section{Results and Discussion}

Experimental results obtained by testing the samples for alloy (Ti6Al4V) produced by using the powder metallurgy technique were presented and discussed with the results obtained, These tests involves [Microstructure examination perform by light optical microscope and SEM, Dry Wear test, Hardness test and Potentiodynamic polarization (corrosion test) ].

\subsection{Microstructure Examination}

The following devices scanning electron microscope (SEM) and Light optical microscope are used to observe the microstructure after etched samples. The samples were etched to show the grain and grain boundaries in the microstructure.When sintering at high temperatures and for long periods of time occur, the gaps are transformed from their acute forms to round shapes followed by an increase in density due to long time in stay. Particle size is a significant factor in conclusion the final properties for compressed parts. Smaller particle size lead to the smaller percentage of gaps to the total volume [11]. Spherical particles produce a regular distribution of porosity. Microstructure is an essential property for determining properties such as hardness, fatigue resistance and fracture strength [11]. Sintering was performed on three samples of the (Ti6Al4V) for different periods of time. Period of stay for the first sample at $\left(1100{ }^{\circ} \mathrm{C}\right)$ temperature was (one hour) and the stay period for the second sample was (two hours) at $\left(1100{ }^{\circ} \mathrm{C}\right)$ temperature, while the stay period for the third sample was (three hours) at $\left(1100{ }^{\circ} \mathrm{C}\right)$ temperature. After examining the Microstructure of the three samples by microscope, The $\alpha$ - phase can be observed, which provides good wear resistance, good weldability and resistance to creep. Bphase, which is ensures good ductility. In addition, we note that the last sample with a three-hours stay period has a beta phase that is more diffusion than the other samples, The grain boundaries are also clear. as shown in the figures (1),(2) and (3). 


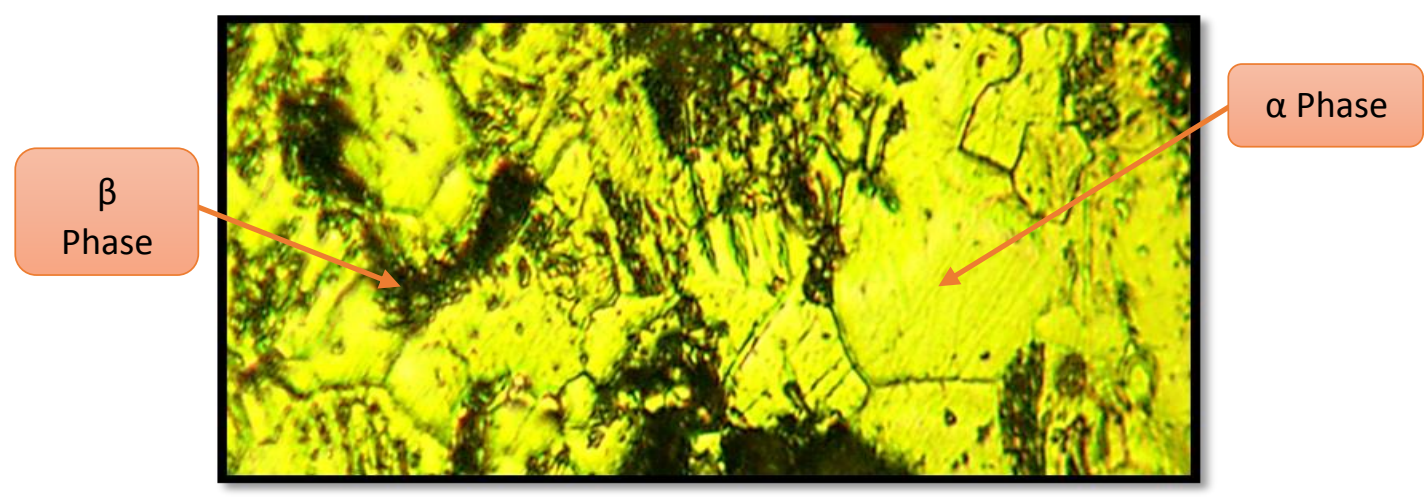

Figure (2): Microstructure of Ti6Al4V alloy after sintering 1hr. (100X).

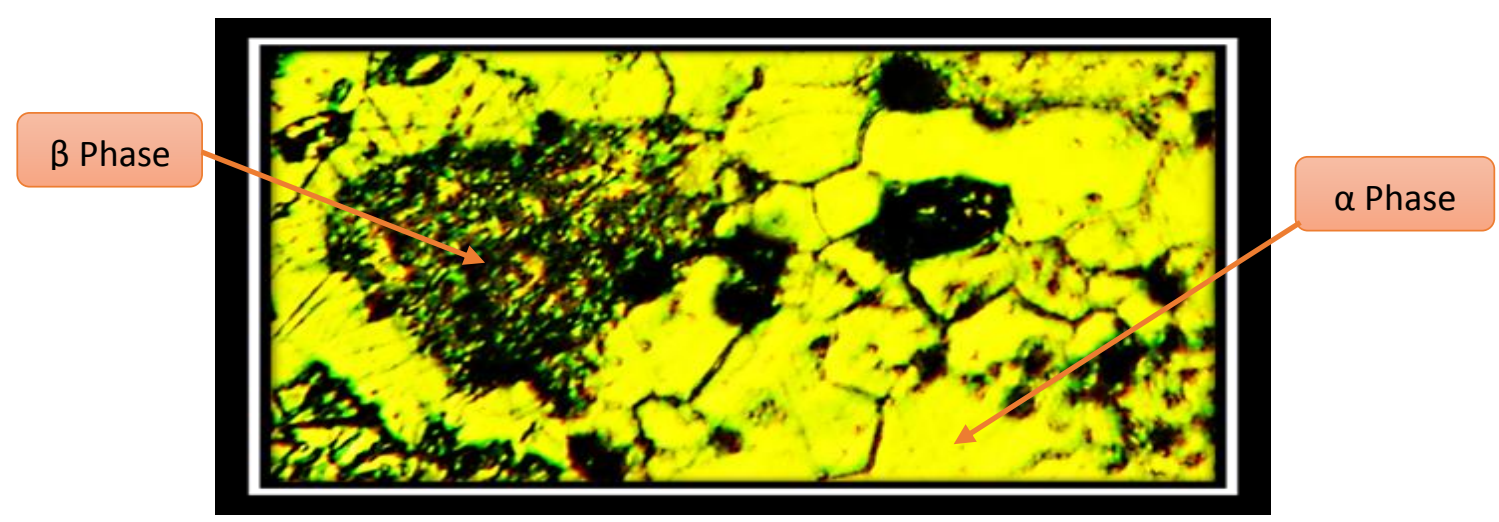

Figure (3): Microstructure of Ti6Al4V alloy after sintering 2hrs. (200X).

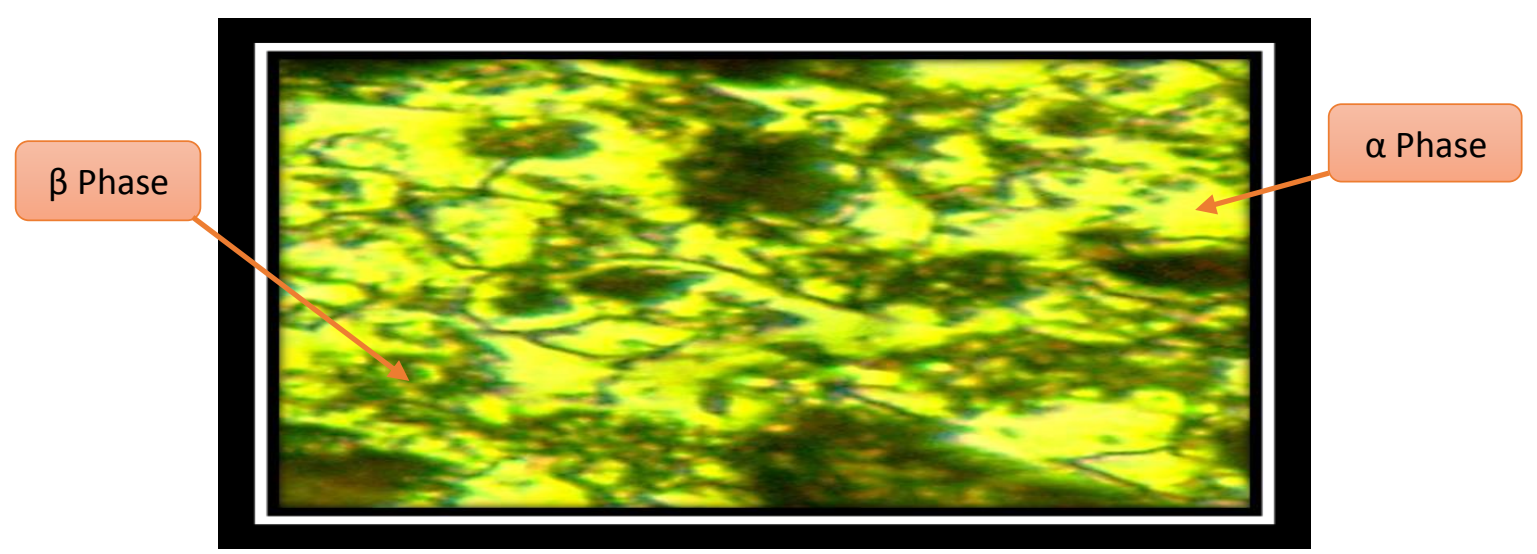

Figure (4): Microstructure of Ti6Al4V alloy after sintering 3hrs. (200X).

SEM pictures are very sensitive to chemical composition, therefore the pictures show the microstructure of samples which contain two phases $[\alpha$ (White region) and $\beta$ (Black region)]. 


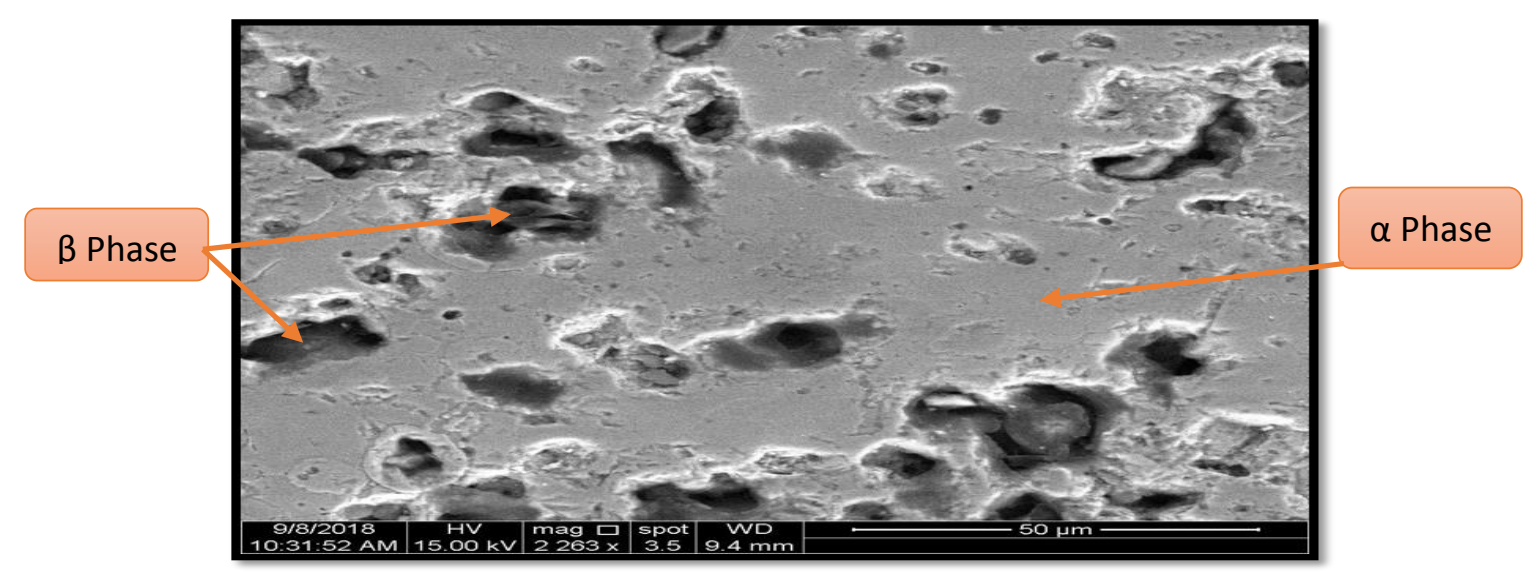

Figure (5): SEM Microstructure Images of Ti6Al4V after sintering process ( 3 hours at $\left.1100{ }^{\circ} \mathrm{C}\right)$

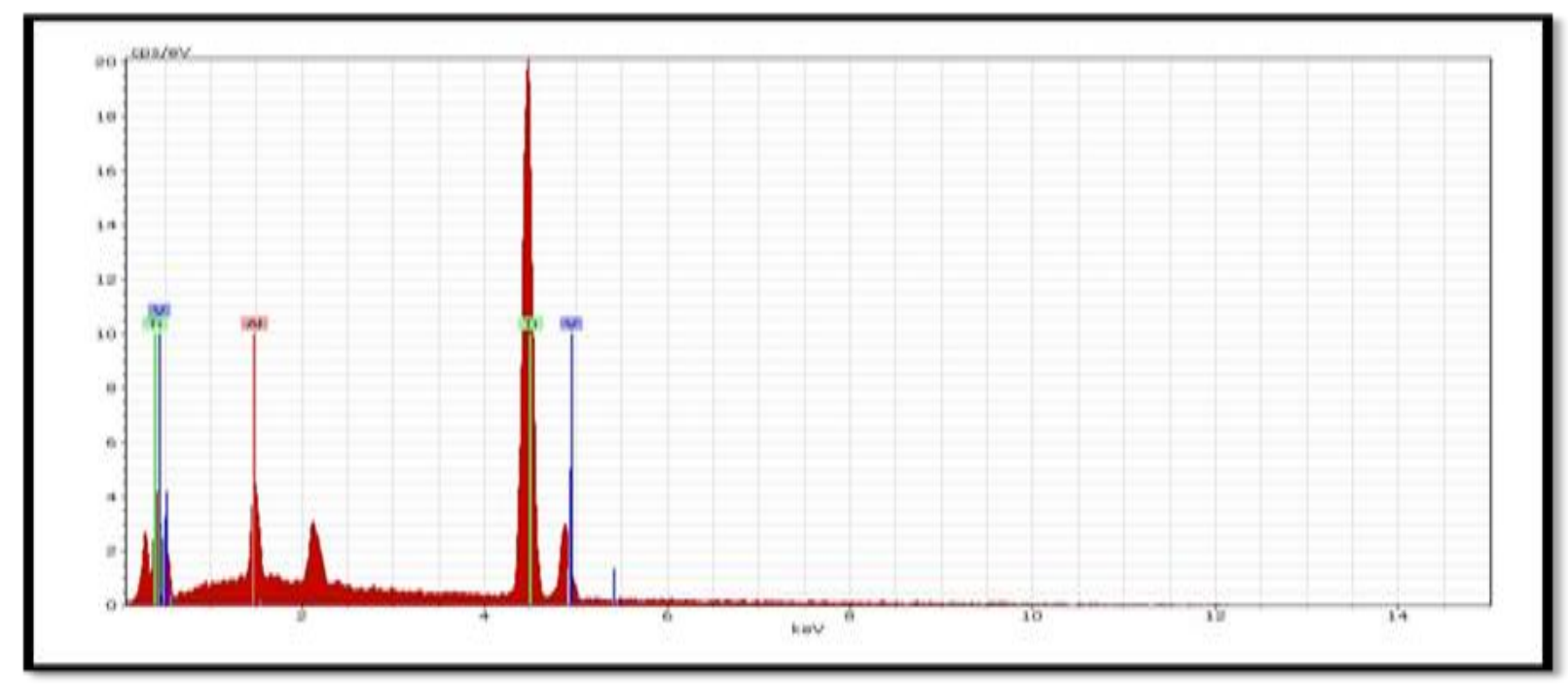

Figure (6): EDS of (Ti6Al4V) sample after sintering process ( 3 hours at $1100{ }^{\circ} \mathrm{C}$ )

\subsection{Hardness Test}

The increase in temperature causes a change in the Microstructure of the samples, and that the heating for long periods lead to increased density and reduce porosity, as the values of hardness increases with the reduction of porosity, the increase in time and temperature lead to increased incidence of diffusion and hardness values rely heavily on porosity and the proportion of phases.Table (4) illustrate the Hardness for three samples of alloy (Ti6Al4V). The first sample has a (one-hour) stay at $1100{ }^{\circ} \mathrm{C}$ and the second sample has a stay time of (two hours) at $1100{ }^{\circ} \mathrm{C}$ and the third sample has a (three-hours) stay at $1100{ }^{\circ} \mathrm{C}$ using the Vickers Hardness Test.

\section{Table (4): Vickers Hardness of alloy at different period of staying}

\begin{tabular}{|c|c|c|}
\hline Alloy & Period of staying (hours) & Vickers hardness (HV) \\
\hline \multirow{3}{*}{ Ti6Al4V } & 1 hour & 343 \\
\cline { 2 - 3 } & 2 hours & 528.56 \\
\cline { 2 - 3 } & 3 hours & 532.66 \\
\hline
\end{tabular}

\subsection{Wear Test}

Samples of alloy (Ti6Al4V) with $13 \mathrm{~mm}$ diameter were sintered in different conditions. The first sample had a one - hour incubation time at $\left(1100{ }^{\circ} \mathrm{C}\right)$ and the second sample had a two-hours stay at $\left(1100{ }^{\circ} \mathrm{C}\right)$ while the third sample had a three - hours stay at a temperature $\left(1100{ }^{\circ} \mathrm{C}\right)$. These samples have been tested for dry wear with different loads $(10$, 
15 and 20) $\mathrm{N}$ and different times also (5, 10, 15, 20 and 25) min using dry sliding wear. The results as shown in the following Figures (6), (7) and (8) which show the Volume Loss versus time.

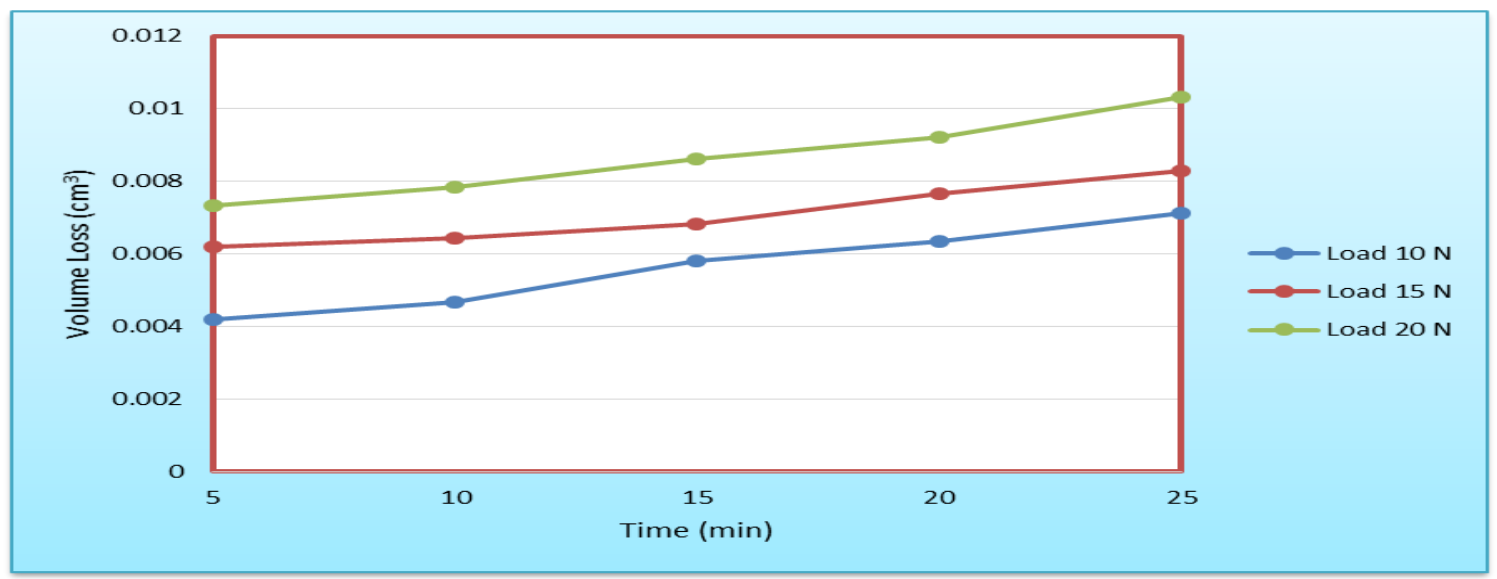

Figure (7) Volume Loss vs Time of alloy (Ti6Al4V) in Period of stay (1hr.) at $1100{ }^{\circ} \mathrm{C}$.

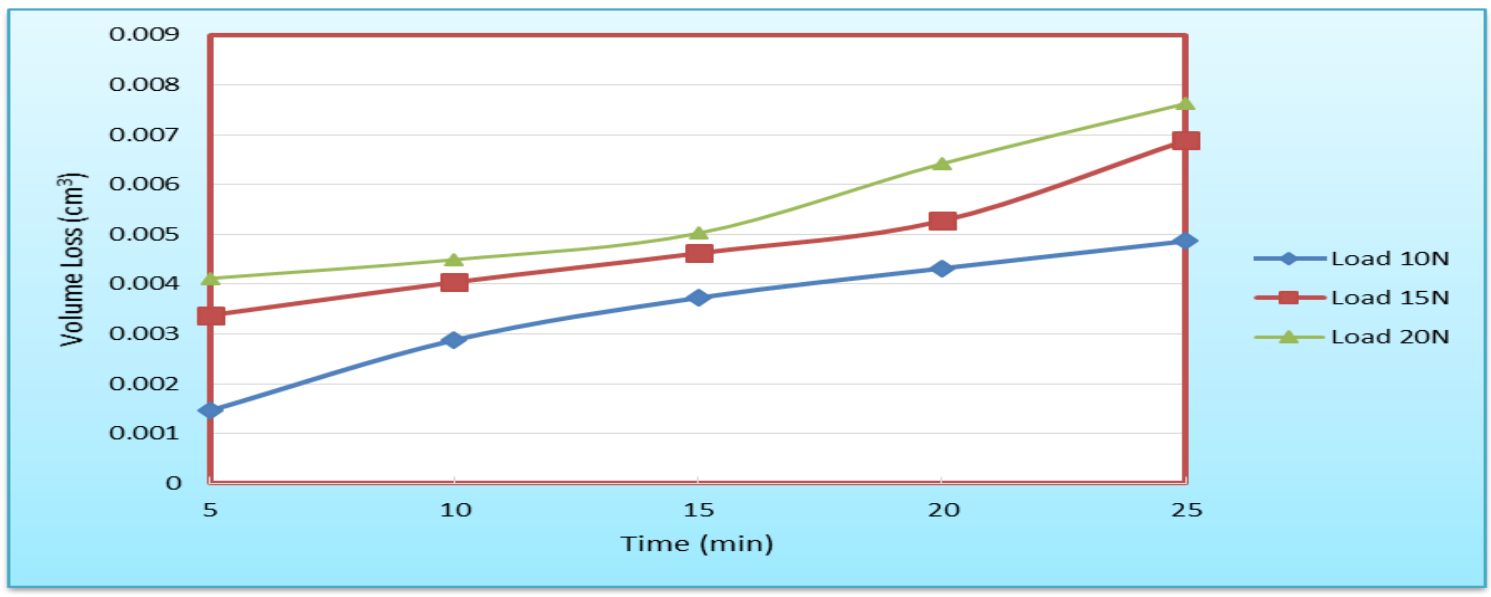

Figure (8) Volume Loss vs Time of alloy (Ti6Al4V) in Period of stay ( 2 hrs.)At $1100{ }^{\circ} \mathrm{C}$.

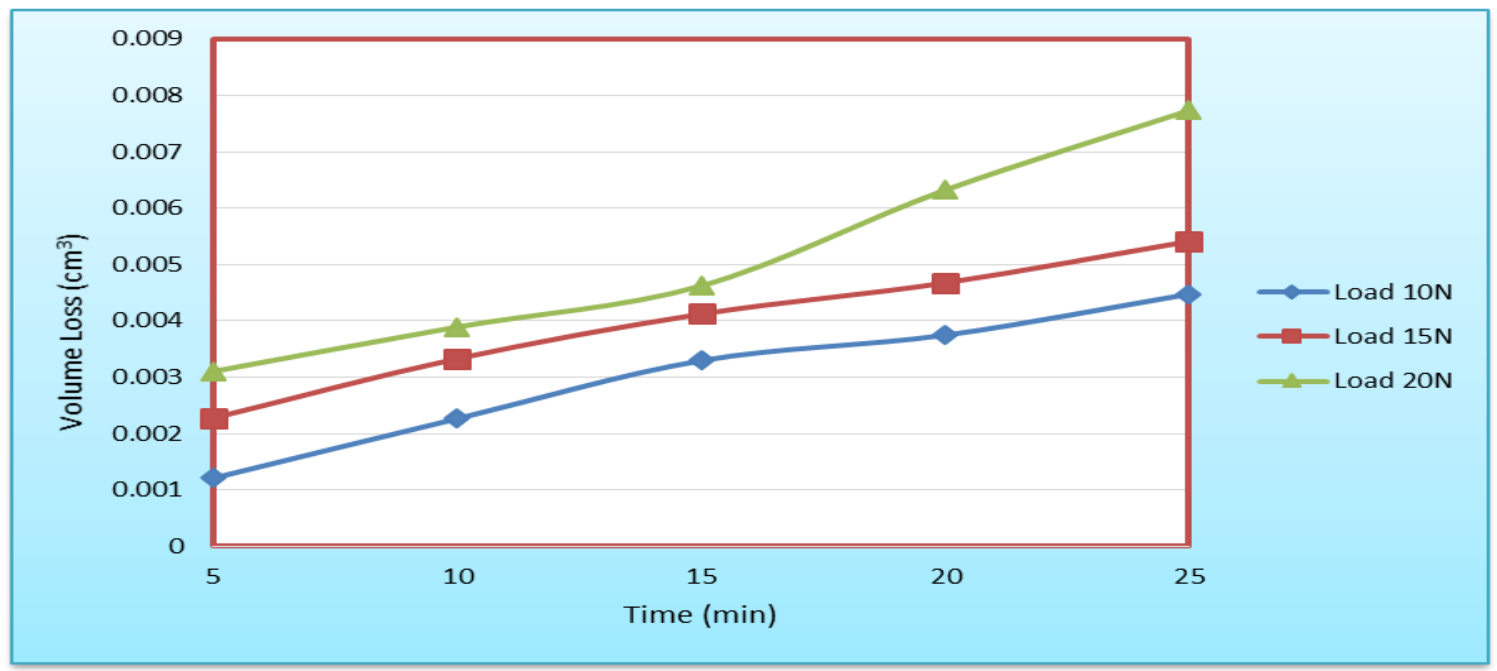

\section{Figure (9) Volume Loss vs Time of alloy (Ti6Al4V) in Period of stay (3 hrs) at $1100{ }^{\circ} \mathrm{C}$}

From these figures, it can be observed that the volume loss of all tested samples at $20 \mathrm{~N}$ load is higher than that under $15 \mathrm{~N}$ and $10 \mathrm{~N}$ and for $15 \mathrm{~N}$ higher than that for $10 \mathrm{~N}$. This is because increasing the load on the surface of the material leads to increased friction and thus increase the amount of material removed. The volume loss increases, when the time increase for all tested specimen, due to 
more time of friction tends to remove more material from the surface there for the increases in volume loss that has been attributed to increase the plastic deformation for the material on the surface [11]. According to the Archard equation, the overall size for wear $(\mathrm{Q})$ is directly proportional to the mounted load (W) and the sliding distance (L) and inversely with the hardness (H) as follows [14].

$$
\mathrm{Q}=\mathrm{K}(\mathrm{WL} / \mathrm{H}) \text {----------------(5)[14] }
$$

Therefore, the material with high hardness becomes low in volume loss. Therefore, the samples which have three different hardness, stay time (1 hour, 2 hours and 3 hours) have different values in the volume loss according to the Argard equation and as shown in the figures $(6,7$ and 8) which represented the volume loss of the studied three samples.

The wear resistance of sample stays ( 3 hours) higher than the samples stay( 2 hours and 1 hour ) because increase the hardness of sample( 3 hours stay), and the wear resistance of sample stay ( 2 hours) is higher than the sample stay (1 hour). Also the weight loss from the sample (3 hours) lower than case ( 2 hours and 1 hour ), this illustration compatible as mentioned from Archard equation which shows higher hardness of these samples leading to lesser volume of weight loss. The load applied and sliding distance from the factors that effect on the weight loss. The sample stay (1 hour) possess higher volume loss at the load $(20 \mathrm{~N})$.

Figures (9), (10) and (11) show by light optical microscope the abrasion wear clearly for wear surfaces of all tested samples.

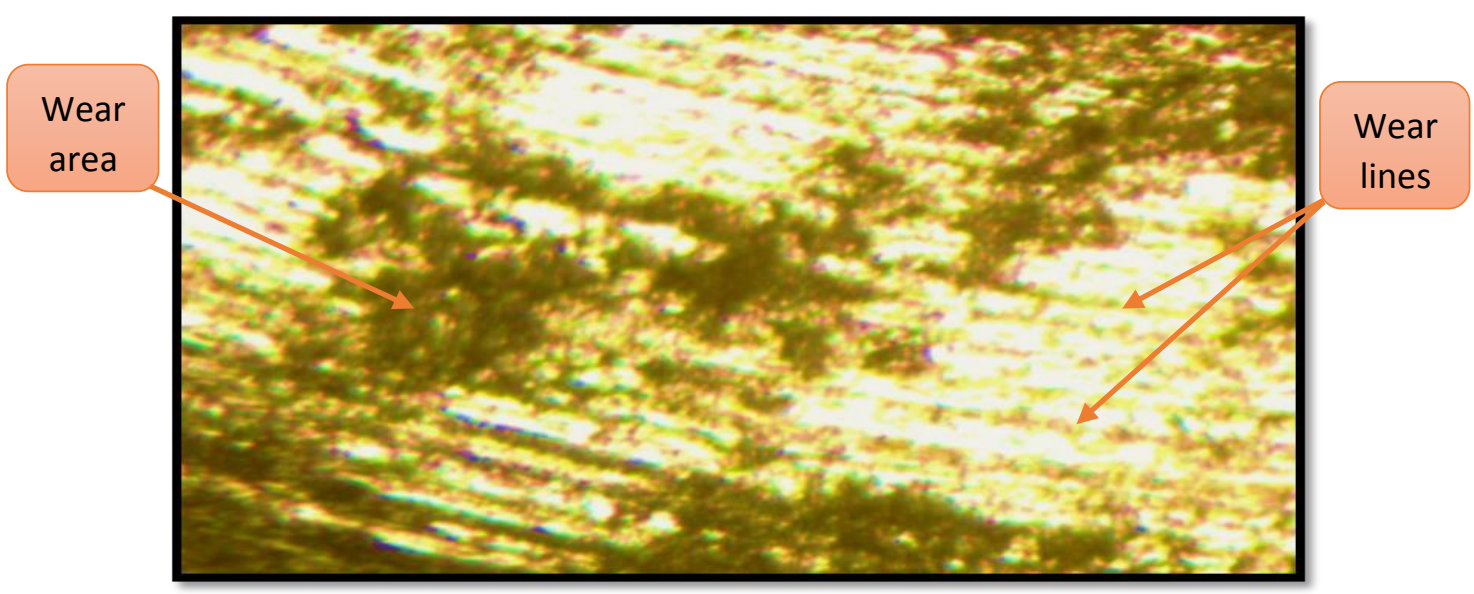

Figure (10): Microstructure for (Ti6Al4V) alloy by Use Light Optical Microscope after Wear Test Under 20N Load and 25minutes time (100X). For a sample staying (1hour at $1100{ }^{\circ} \mathrm{C}$ ) during sintering process.

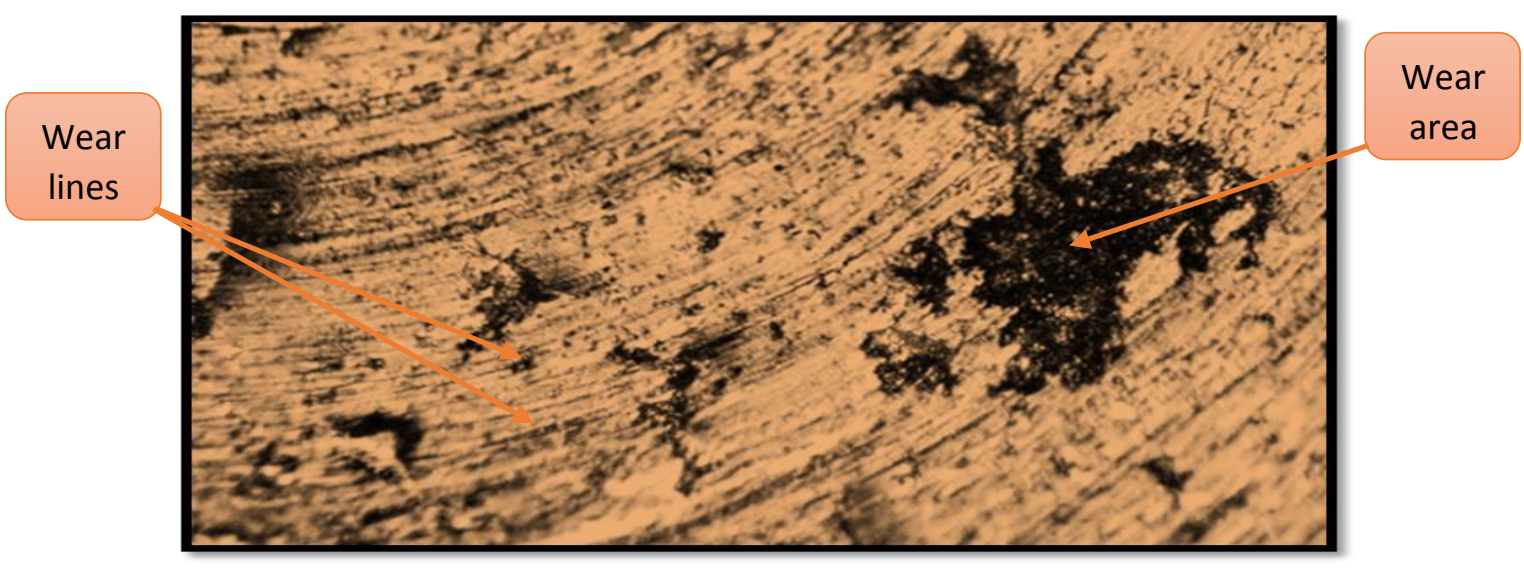

Figure (11): Microstructure for (Ti6Al4V) alloy by Use Light Optical Microscope after Wear Test Under 20N Load and 25minutes time (200X). For a sample staying (2hours at $1100{ }^{\circ} \mathrm{C}$ ) during sintering process. 


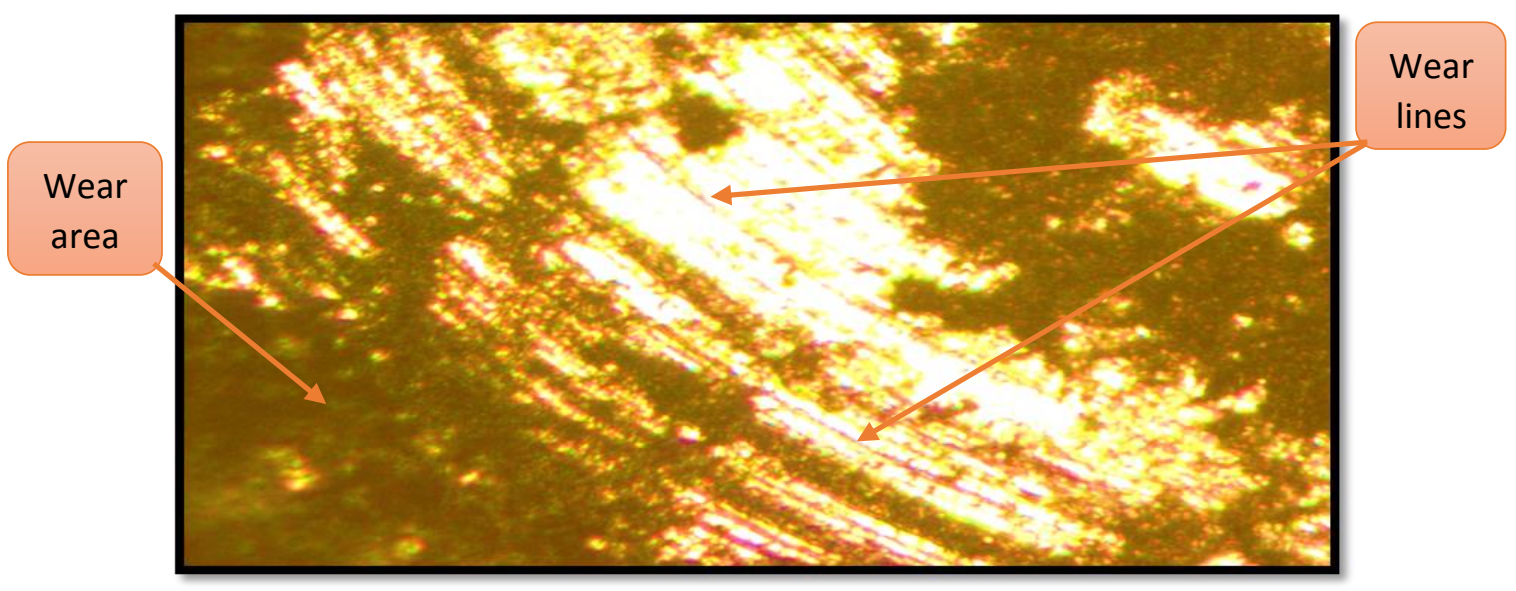

Figure (12): Microstructure for (Ti6Al4V) alloy by Use Light Optical Microscope after Wear Test Under 20N Load and 25minutes time (100X). For a sample staying (3hours at $1100{ }^{\circ} \mathrm{C}$ ) during sintering process.

Figures (9), (10) and (11) show slide grooves are visible on all sample surfaces, due to abrasion wear. Abrasion wear on the worn surface of all samples can be watched easily and plastically deformed occure on the surface because continuing of sliding leading to initiation ridges region and grooves on the wear track. Wear grooves take place because of the penetrating of stiff abrasives tool produced scratching on the surface of sample.The volume loss is less for sample (3 hours staying) also penetration depth is less for this sample.

Figure (12) shows image done by SEM device for wear surfaces of a sample after sintering process (stay 3 hours at $1100{ }^{\circ} \mathrm{C}$ ) then Wear Test Under 20N Load and 25minutes time. These images exhibit darker region, which represent titanium oxides formed. Titanium alloys are naturally oxidized, and these oxides can reduce the frictional force between the surface of samples and the steel ball. Figure (13) represent EDS of the elements components of the alloy after sintering process (3 hours at $1100{ }^{\circ} \mathrm{C}$ ) then Wear Test Under $20 \mathrm{~N}$ Load and 25 minutes time.

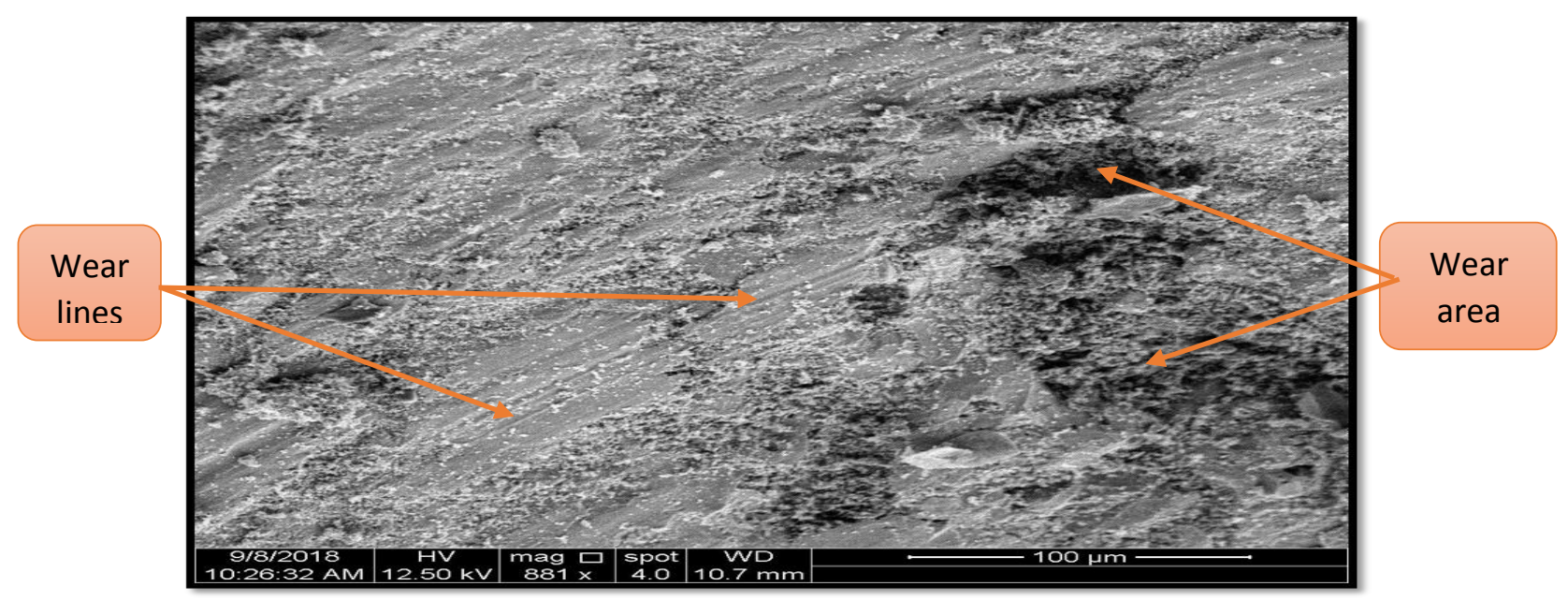

Figure (13) SEM Micrographs Circular Wear Marks on (Ti-6Al-4V) for a Sample sintering $\left(3\right.$ hours at $\left.1100{ }^{\circ} \mathrm{C}\right)$ after that the Wear Test Under 20N Load and 25minutes time. 


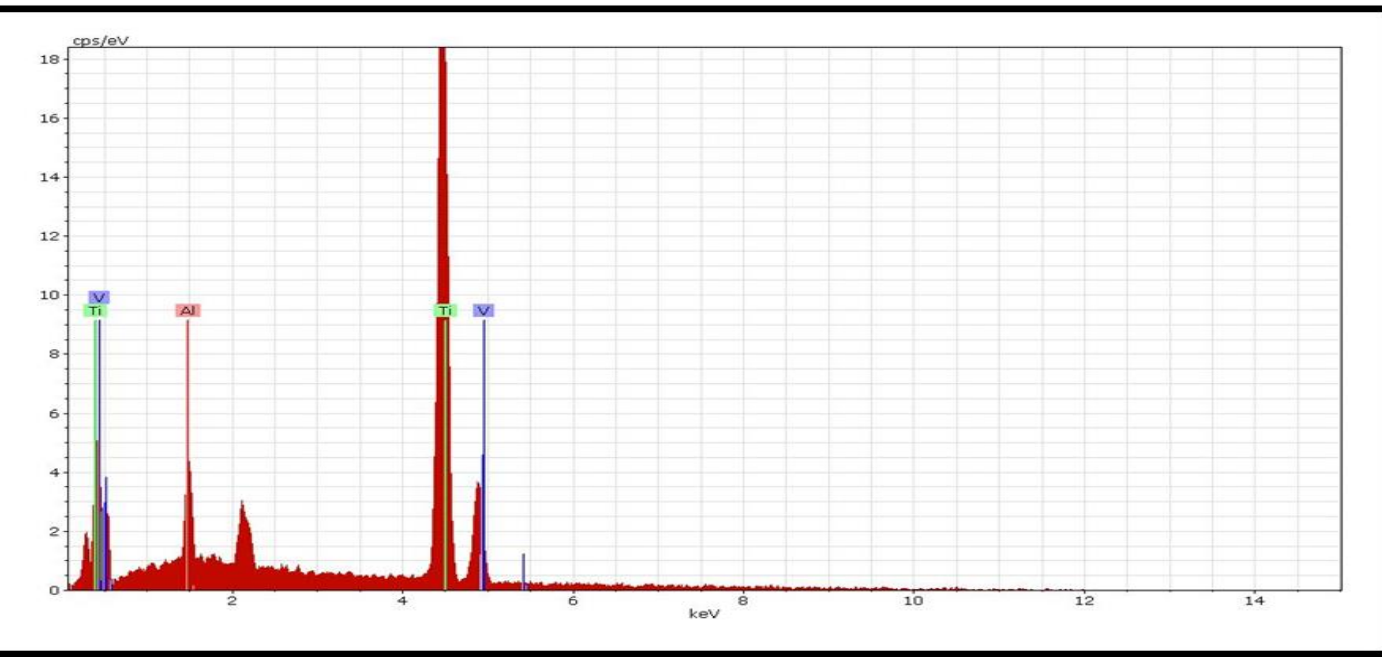

Figure (14): EDS of Ti6Al4V after sintering process $\left(3\right.$ hours at $\left.1100{ }^{\circ} \mathrm{C}\right)$ then Wear Test under 20N Load and 25minutes time.

\subsection{Potentiodynamic Polarization}

The corrosion behavior of the titanium alloy (Ti6Al4V), which have a sintering process at different stays periods $\left(1\right.$ hour, 2 hours and 3 hours, at $1100^{\circ} \mathrm{C}$ ) where studied in solution $(0.9 \mathrm{NaCl})$ for simulating the human body fluid, to learn the behavior of corrosion in these three samples Also influence corrosion process on the microstructure of samples. The results that can be obtained from the corrosion test for a sample in $(0.9 \mathrm{NaCl})$ solution at $37{ }^{\circ} \mathrm{C}( \pm 1)$ were illustrated in tables (5).

Table (5): The results obtained after Corrosion test for samples in $0.9 \mathrm{NaCl}$ Solution at $37^{\circ} \mathbf{C}( \pm 1)$.

\begin{tabular}{|c|c|c|c|}
\hline Alloy(Ti6Al4V) & Icorr. $\left(\mathrm{nA} / \mathrm{cm}^{2}\right)$ & Ecorr. $(\mathrm{mV})$ & Corrosion Rate $(\mathrm{mpy})$ \\
\hline 1 hour stay & 637 & 97 & 1.4283 \\
\hline 2 hour stay & 922.8 & -12.8 & 2.04325 \\
\hline 3 hour stay & 999.5 & 85.2 & 2.277 \\
\hline
\end{tabular}

The obtained results from table (5) showed that the sample which remain (three hours at 1100 ${ }^{\circ} \mathrm{C}$ ) have a higher corrosion current density than the other samples, which have time stayed (two hours and one hour at $1100{ }^{\circ} \mathrm{C}$ ), there fore the sample (three hours staying at $1100{ }^{\circ} \mathrm{C}$ ) have corrosion rate is higher than the remainder of the samples, because high staying period leads to increases the diffusion and increases the contact points between the particles and increase the forces of bonds between the particles and this leads to increased corrosion current density and therefore the oxidation process to be a high degree and this leads to the higher rate of corrosion. Titanium alloys are highly resistant to corrosion by forming a layer of metal oxide on the metal surface $(\mathrm{TiO} 2)$, the oxide layer covers the titanium and its alloys surface. At $900{ }^{\circ} \mathrm{C}$ the Oxide layers may formed, but these layer break at 1100 ${ }^{\circ} \mathrm{C}$, possibly due to an exceeding growth and stresses can be very higher [15].

The microstructure after corrosion tests for samples which remain (1 hour , 2 hours and 3 hours at $1100{ }^{\circ} \mathrm{C}$ ) during sintering process illustrated as shown in figures below (14),(15) and (16), done by using light optical microscope . 


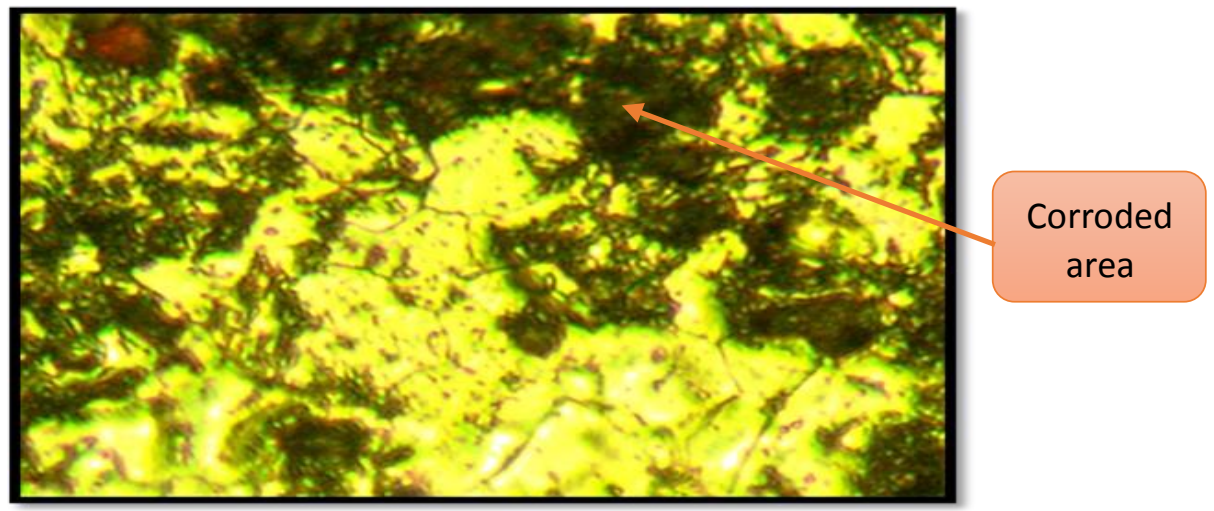

Figure (15): Microstructure of Corroded sample sintering (1 hour at $\left.1100{ }^{\circ} \mathrm{C}\right)$ Ti6Al4V Alloy (200X) with 0.9NaCl Solution.

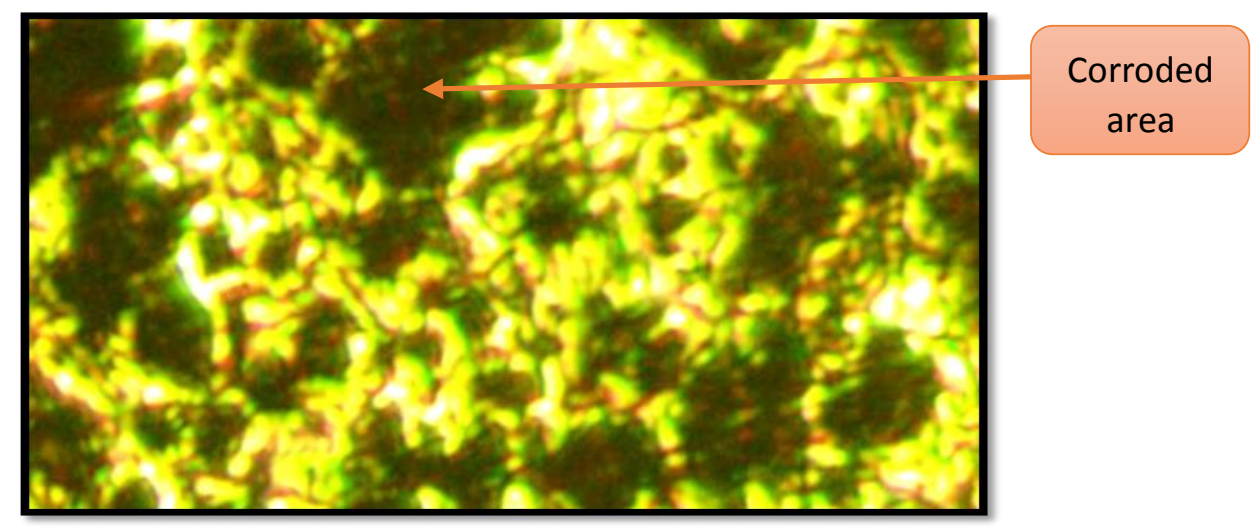

Figure (16): Microstructure of Corroded sample sintering ( 2 hours at $1100{ }^{\circ} \mathrm{C}$ ) Ti6Al4V Alloy (200X) with $0.9 \mathrm{NaCl}$ Solution.

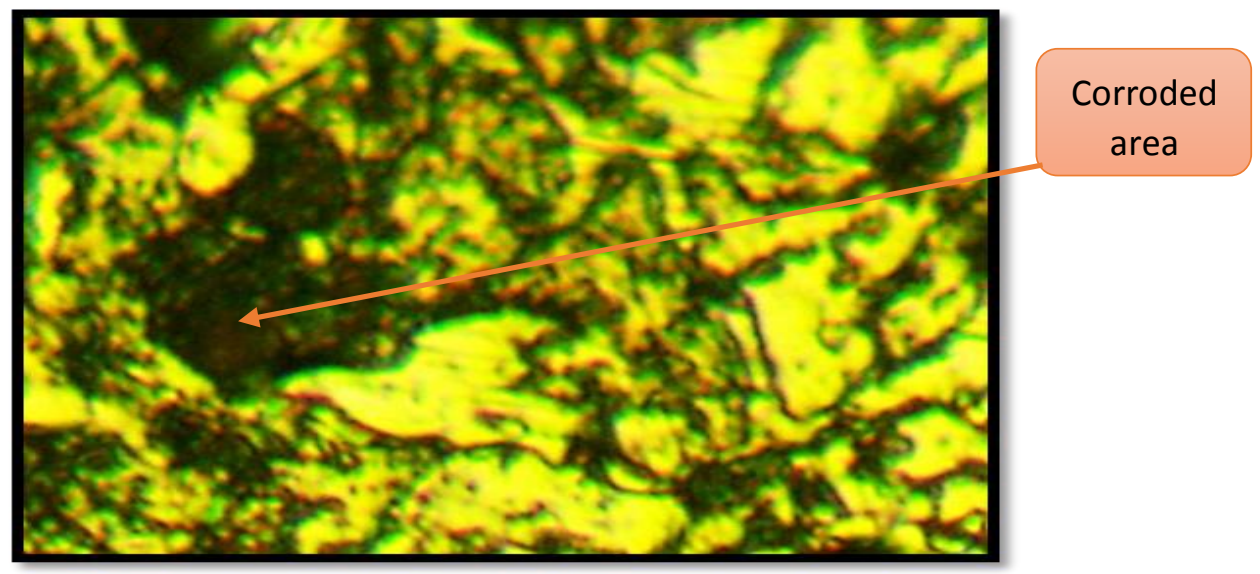

Figure (17): Microstructure of Corroded sample sintering ( 3 hours at $1100{ }^{\circ} \mathrm{C}$ ) Ti6Al4V Alloy (200X) with 0.9NaCl Solution.

The color of the surface samples has changed because of the corrosion product and this evidence that the corrosion has take place on the surface. Figures (17), (18) and (19) represent polarization curves for samples, which remain $\left(1\right.$ hour, 2 hours and 3 hours at $\left.1100^{\circ} \mathrm{C}\right)$ during sintering process then corrosion test in $0.9 \mathrm{NaCl}$ solution. 


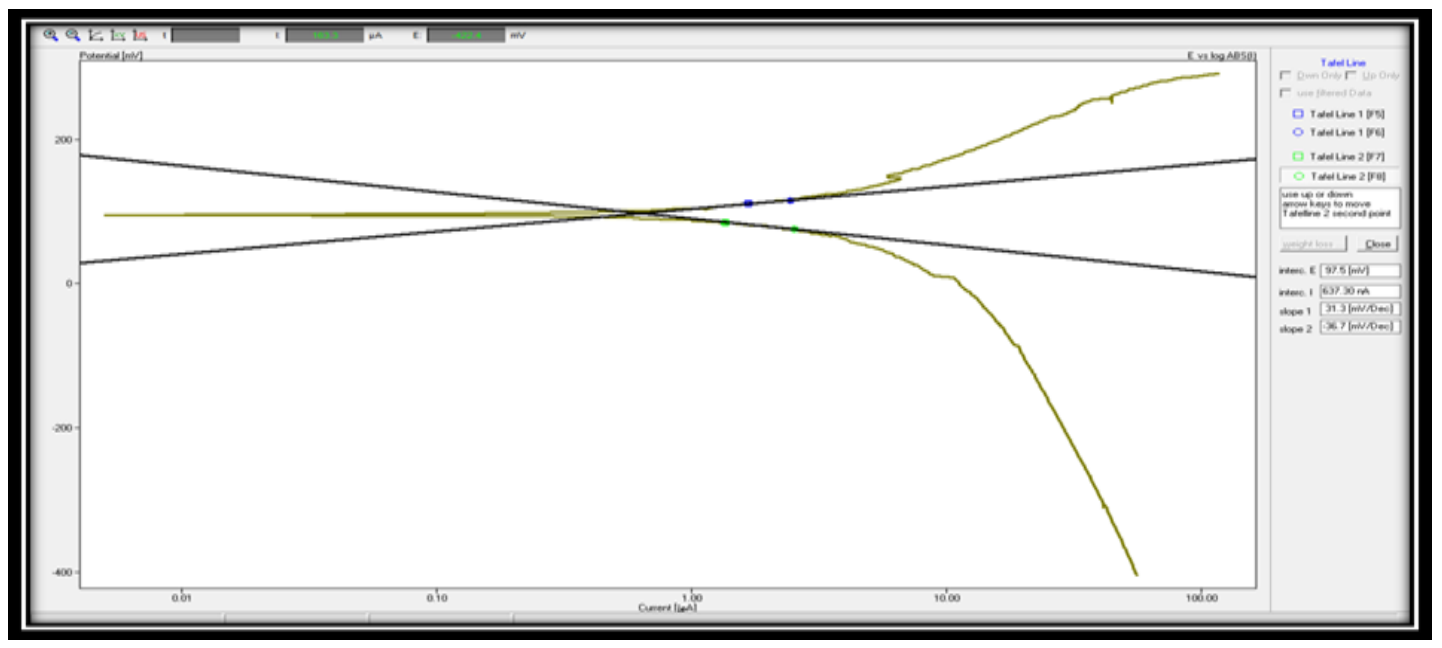

Figure (18): Potentiodynamic Polarization for sample (Ti6Al4V) in a solution of $0.9 \mathrm{NaCl}$, which remain $\left(1\right.$ hour at $\left.1100{ }^{\circ} \mathrm{C}\right)$ during sintering process.

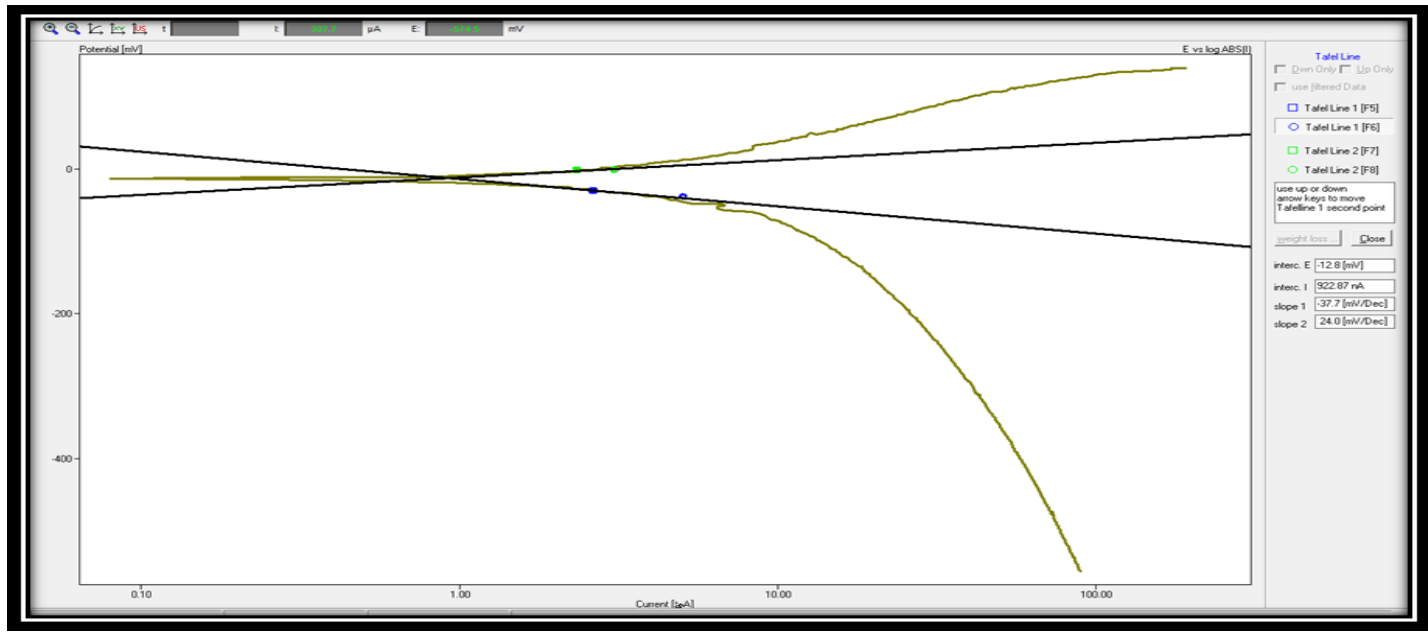

Figure (19): Potentiodynamic Polarization for sample (Ti6Al4V) in a solution of $0.9 \mathrm{NaCl}$, which remain $\left(2\right.$ hours at $\left.1100{ }^{\circ} \mathrm{C}\right)$ during sintering process.

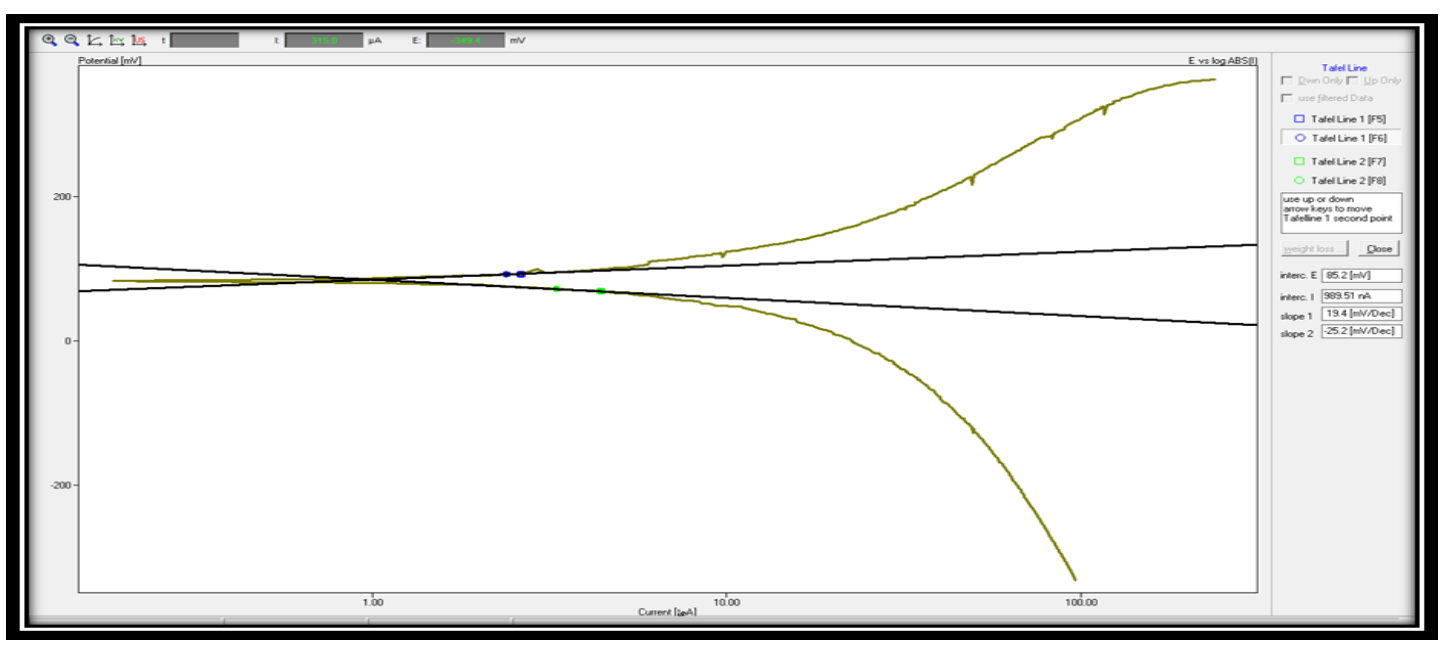

Figure (20): Potentiodynamic Polarization for sample (Ti6Al4V) in a solution of $0.9 \mathrm{NaCl}$, which remain $\left(3\right.$ hours at $\left.1100{ }^{\circ} \mathrm{C}\right)$ during sintering process. 
Figure (20) shows the SEM image to observe corrosion area on the surface with black color because of the corrosion products, and from that color it can be estimated that the corrosion has taken place on the surface.

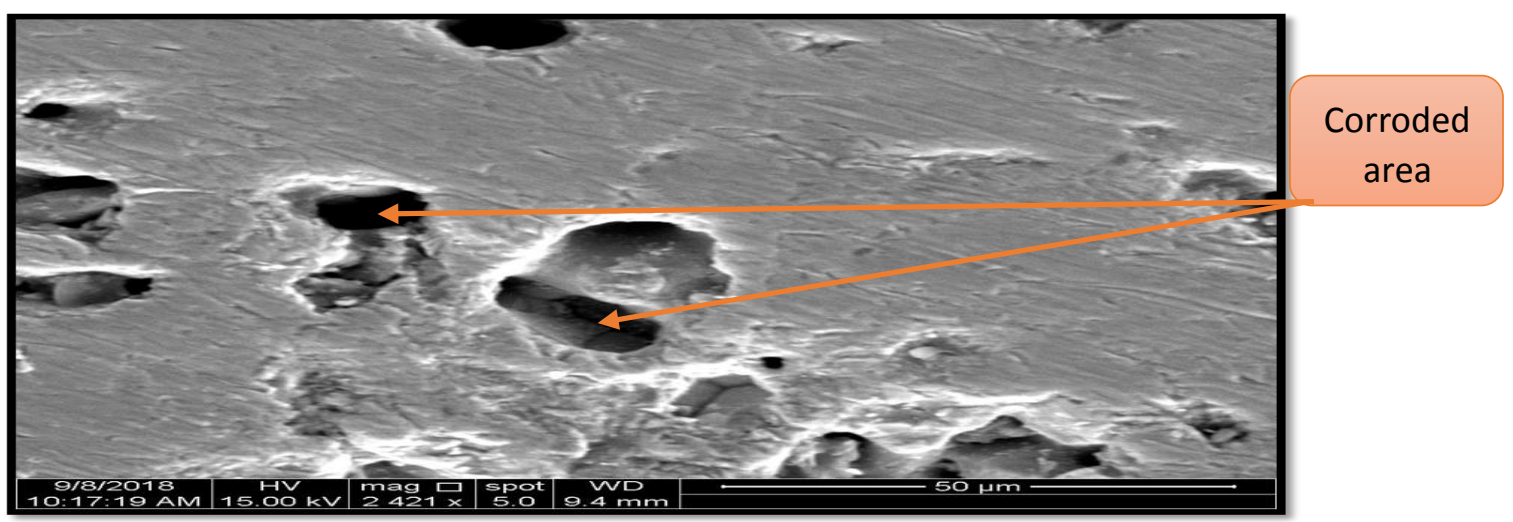

Figure (21): SEM Micrograph for sample sintering $\left(2\right.$ hours at $\left.1100{ }^{\circ} \mathrm{C}\right)$ after that corrosion test in $0.9 \mathrm{NaCl}$ Solution.

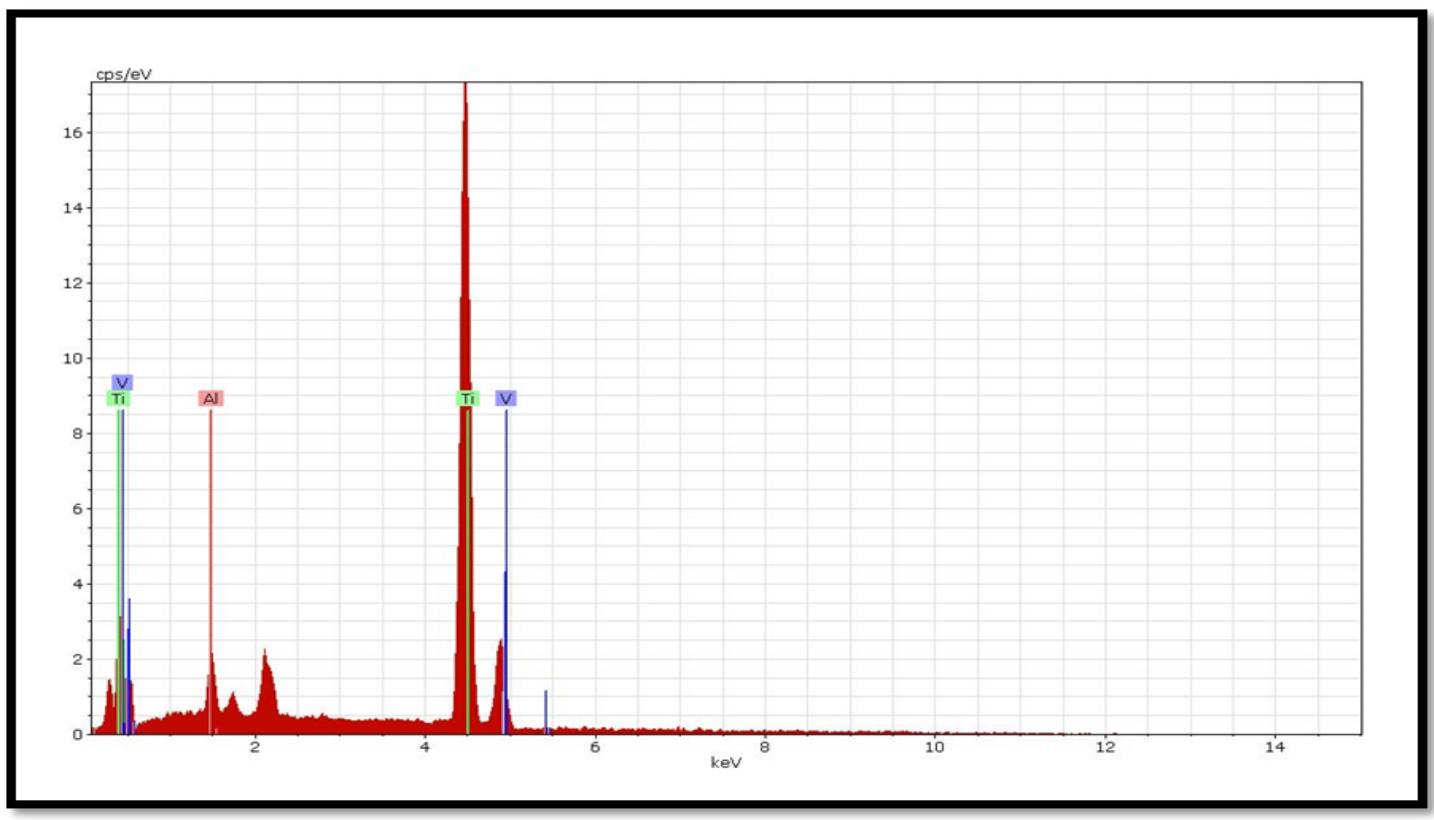

Figure (22): EDS of (Ti6Al4V) after sintering process $\left(2\right.$ hours at $\left.1100{ }^{\circ} \mathrm{C}\right)$ then corrosion test in $0.9 \mathrm{NaCl}$ Solution.

\section{Conclusions}

1- The porosity of the samples decreases at high temperatures and time of stay to a certain limit and then increase porosity at very high temperatures.

2- The sintering process for the green samples by increasing the temperature and time lead to increase the hardness of the alloy.

3- The volume loss is inversely proportional to the hardness, where increased hardness leads to a decrease in volume loss.

4- Titanium alloys are highly resistant to corrosion by forming a layer of metal oxide on the metal surface $(\mathrm{TiO} 2)$.

5- The sample which remains ( 3 hours at $1100 \mathrm{C}^{\circ}$ ) have a higher corrosion current density and have corrosion rate is higher than the other samples. 


\section{CONFLICT OF INTERESTS.}

- There are no conflicts of interest.

\section{References}

[1] Niinomi, M. 'Recent metallic materials for biomedical applications' Metallurgical and materials transactions A, 33(3), 477-486, 2002.

[2] Ostomel, T. A., Shi, Q., Tsung, C. K., Liang, H., \& Stucky, G. D. Spherical bioactive glass with enhanced rates of hydroxyapatite deposition and hemostatic activity. Small, 2(11), 1261-1265, 2006.

[3] Standard, A. S. T. M., 'F67-06: Standard specification for unalloyed titanium for surgical implant applications. ASTM International', West Conshohocken, PA, 2006.

[4] Manam, N. S., Harun, W. S. W., Shri, D. N. A., Ghani, S. A. C., Kurniawan, T., Ismail, M. H., \& Ibrahim, M. H. I. Study of corrosion in biocompatible metals for implants: A review. Journal of Alloys and Compounds, 701, 698-715, 2017.

[5] Yamamoto, A., Honma, R., \& Sumita, M. Cytotoxicity evaluation of 43 metal salts using murine fibroblasts and osteoblastic cells'Journal of Biomedical Materials Research Part A, 39(2), 331-340, 1998.

[6] Landuci, M. C. ' Caracterização das propriedades mecânicas de biomateriais metálicos', 2016.

[7] Shoesmith, DW and JJNoël ' Corrosion of Titanium and Its Alloys'The University of Western Ontario, London, ON, Canada VE Annamalai, SSN College of Engineering ,Chennai, 2016, India.

[8] Iijimaa, D.T. Yoneyamab, H. Doib, H. Hamanakab, N. Kurosakia 'Wear properties of Ti and Ti-6Al-7Nb castings for dental prostheses' aDepartment of Oral Diagnosis and General Dentistry, Graduate School, Tokyo Medical and Dental University, 1-5-45 YushimaBunkyo-ku,Tokyo 113-8549, Japan, 2003.

[9] Askeland D.R., P.P. Phulke,'The Science and Engineering of Materials' Fifth ed, Thompson Publishers, USA, p. 520, 2005.

[10] Gawad. S.M. "Effect of $(\mathrm{Cu} \& \mathrm{Cr})$ Additives on Corrosion and Dry Sliding Wear of NiTi Shape Memory Alloy", MS.C thesis, materials engineering college, university of Babylon / Iraq, 2015.

[11] Mohammad Luay Aziz Ahmed "Comparison Study between Titanium Base Alloys Used in Human Body" MS.C thesis, materials engineering college, university of Babylon / Iraq, 2018.

[12] Alher M. A. 'Ni ion release of Tio2 and Tio2 / Hydroxylapatite composite coatings formed on niti shape memory alloy produced by powder metallurgy' Ph.D. thesis, Production Engineering and Metallurgy Department, University of Technology, BaghdadIraq, 2013.

[13] Jabber. H.H., 'The Effect of Addmixed Ti on Corrosion Resistant of High Copper Dental Amalgam' journal of Babylon University, vol. 22, no. 2.pp. 413-421, 2014.

[14] Prof Abdul Wahid Kazem "Metallurgical Engineering and Advanced Materials" materials engineering college, university of Babylon / Iraq, 2016.

[15] Bautista A.*, Moral C., Blanco G., and Velasco F. " Influence of sintering on the corrosion behavior of a Ti-6Al-4V alloy".Journal of Materials and Corrosion 2005, 56, No. 2, 2005. 


\section{تأثير المعاملات الحرارية على خواص سبيكة التيتانيوم الطبية الحياتية جاسم محمد سلمان المرشدي باسم جابر غايب \\ كلية هنسة المواد، جامعة بابل، بابل، العراق باقي}

bassimjaber888@gmail.com_jmsmaterials@yahoo.com

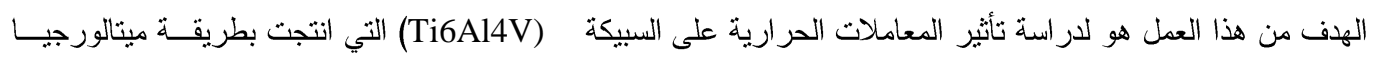

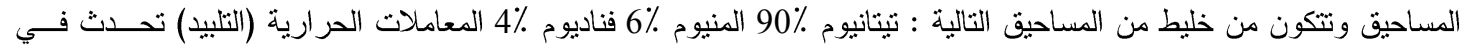

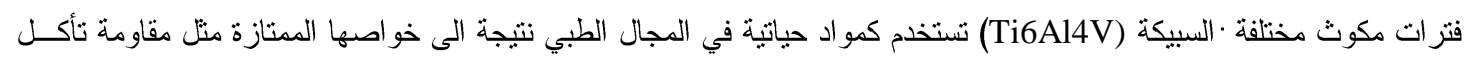

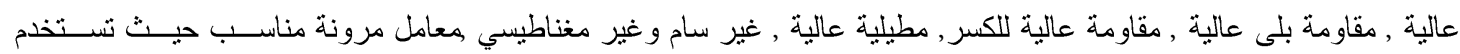

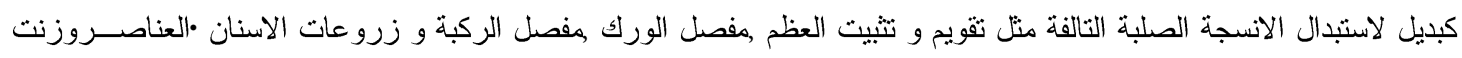

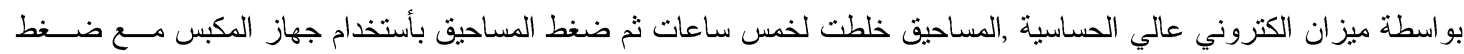

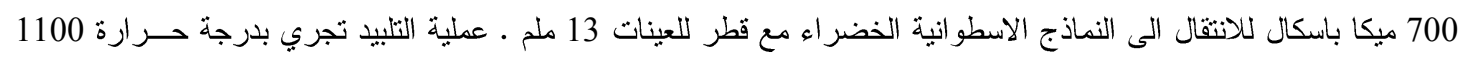

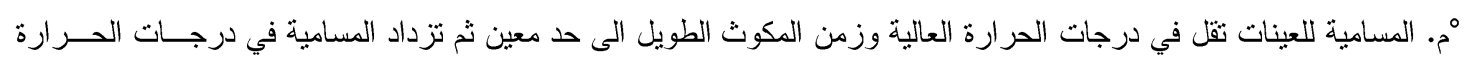

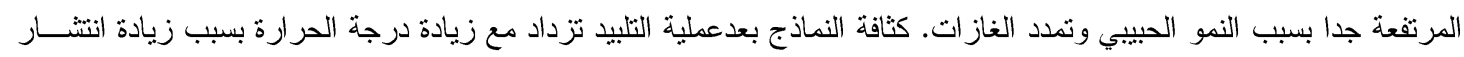

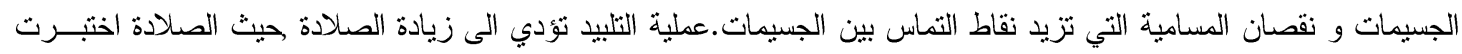

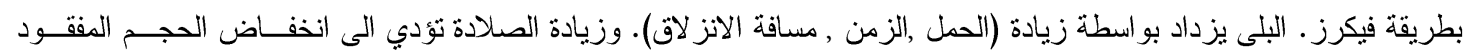

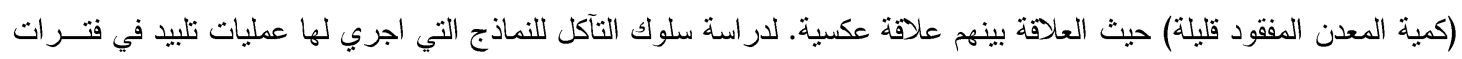

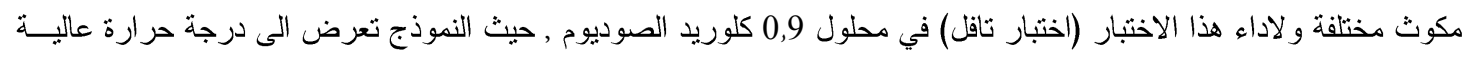

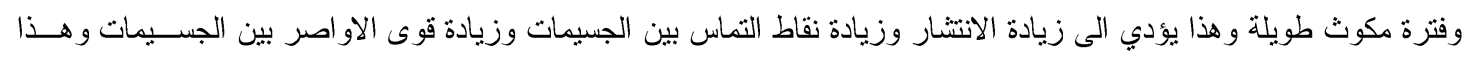
يؤدي الى زيادة تبار التاكل ولذلك عملية الاكسدة على درجة عالية و هذا يؤدي الى معدل التآكل. الكلمات الدالة: السبيكة الحياتية، سبيكة التيتانيوم، المعاملات الحرارية، الخواص الميكانيكية. 